Jurnal CARE, Vol. 2, No. 2, 2014

\title{
PENGARUH SHOLAT TAHAJUD TERHADAP DEPRESI PADA SANTRI DI PESANTREN AN-NUR 2 BULULAWANG MALANG
}

\author{
Esti Widiani ${ }^{1)}$ \\ Doddy Indrawan ${ }^{2)}$ \\ 1), 2) Program Studi Ilmu Keperawatan, Fakultas Ilmu Kesehatan \\ Universitas Tribhuwana Tunggadewi Malang \\ email: diani.esti@gmail.com
}

\begin{abstract}
Depression is a problem that is associated with the natural feeling. Depression should be handled appropriately and accurately so as to provide healing benefits. Tahajud prayers, prayers are held in the evening is very beneficial for the body. The purpose of this study was to analyze the influence of depression on praying tahaijud on students in pesantren An-Nur 2 Bululawang Malang. This research design using pre experimental design approach one group pre test post test design. Sampling was done by purposive sampling as many as 6 people. Analysis of the data used is the Wilcoxon test with $a=0.05$. Levels of depression before treatment as much as $17 \%$ of respondents experiencing severe levels of depression and very heavy, and as much as $66 \%$ of respondents experienced moderate depression. Given the results obtained after treatment by $17 \%$ of respondents experiencing severe levels of depression, depression levels as much as $66 \%$ lighter and $33 \%$ of respondents did not have depression. From the analysis results obtained p-value of $0.027<0.05$ then the null bypothesis is rejected, so it is concluded that there are influences on depression tabajud prayer on students at An-Nur Islamic School 2 Bululawang Malang. From the results of the study suggest tahajud prayers could be one method of treatment for depression boarding school area
\end{abstract}

Keywords: Depression, Prayer Tahajud.

\section{PENDAHULUAN}

Depresi merupakan satu masa terganggunya fungsi manusia yang berkaitan dengan alam perasaan yang sedih dan gejala penyertanya, termasuk perubahan pada pola tidur dan nafsu makan, psikomotor, konsentrasi, anhedonia, kelelahan, rasa putus asa dan tidak berdaya serta bunuh diri (Kaplan, 2010 dalam Sari, 2011).

Fenomena tindak kejahatan, stres, depresi, dan skizofrenia yang ada di Indonesia semakin banyak terjadi dan semakin bertambah setiap tahunnya. Problema ini tidak hanya dialami oleh orang dewasa saja, tetapi juga anak-anak, remaja, dewasa, dan pada usia lanjut. Banyak kita temui kasus-kasus bullying ataupun pemerkosaan yang dilakukakan oleh anak $\mathrm{SD}$, begitu juga pada remaja, dimana banyak remaja yang mengalami stress, depresi akibat dari permasalahan yang tidak dapat diselesaikan seperti patah hati yang akhirnya berujung pada percobaan bunuh diri. Begitu juga oleh kasus-kasus yang dihadapi oleh orang dewasa ataupun lansia yang tidak jauh dari fenomena-fenomena tersebut.

Depresi merupakan penyakit serius yang diderita jutaan orang dengan berbagai macam gejala.Menurut data Badan Kesehatan Dunia (WHO dalam Marianne, 2010) saat ini sekitar 5-10 persen orang di dunia mengalami depresi. Penelitian yang dilakukan Persatuan Dokter Spesialis Kesehatan Jiwa menunjukkan, sebagian besar masyarakat Indonesia mengidap depresi, dari tingkat yang ringan sampai berat. "Hasil penelitian dokter kesehatan jiwa menunjukkan, 94 persen masyarakat saat ini mengidap depresi", kata Ketua Umum Ikatan Dokter Indonesia (Dalam Liza, 2013).

Banyak faktor penyebab depresi yang bisa di jelaskan secara ilmiah. Tetapi, faktorfaktor penyebab depresi tersebut biasanya 
Jurnal CARE, Vol. 2, No. 2, 2014

tidak langsung menyebabkan gangguan terhadap penderitanya, tetapi faktor penyebab tersebut menjadi bahaya laten, yang akan muncul dikemudian hari jika terjadi sesuatu yang bisa menjadi faktor pemicunya.

Gangguan depresi pada umumnya dicetuskan oleh peristiwa hidup tertentu.Kenyataannya peristiwa hidup tersebut tidak selalu diikuti depresi, hal ini mungkin disebabkan karena ada faktorfaktor lain yang ikut berperan mengubah atau mempengaruhi hubungan tersebut (Lumongga, 2009 dalam Supiandi, 2012).

Faktor sholat berpengaruh pada depresi menurut penelitian Kaelber tahun 2002 (dalam Ahmad, 2011) menjelaskan bahwa dewasa ini penduduk wanita yang mengalami depresi antara 10\% sampai 15\% dan pada pria antara $5 \%$ sampai $12 \%$, ini disebabkan karena orang telah meninggalkan agama dalam kehidupan, dan banyak karya ilmiah yang menyimpulkan bahwa komitmen agama bermanfaat bagi upaya pencegahan depressi dan dapat bertindak sebagai kekuatan pelindung dan penyangga seseorang dari resiko menderita depresi (Prof. Dr. Dadang Hawari, dalam Rusdy, 2011)

Problema tersebut merupakan pokok bahasan yang penting, dimana negara Indonesia yang merupakan mayoritas bergama Islam tetapi mengapa memiliki tingkat kejahatan, stres, depresi, dan skizofrenia yang cukup tinggi. Mengapa bisa terdapat permasalahan seperti demikian? Jika menilik dari Al-Quran pada surat AlAnkabut: 45;

"Bacalah apa yang telah diwahyukan kepadamu, Yaitu Al kitab (Al Quran) dan dirikanlah shalat.Sesungguhnya shalat itu mencegah dari (perbuatan- perbuatan) keji dan mungkar. Dan sesungguhnya mengingat Allah (shalat) adalah lebih besar (keutamaannya dari ibadah-ibadah yang lain). Dan Allah mengetahui apa yang kamu kerjakan."

Dari redaksi ayat di atas, maka sebenarnya bisa menjawab pertanyaan tersebut. Sebab sholat merupakan ukuran ataupun cerminan dari perbuatan manusia. Jika seseorang tetap melakukan perbuatan kejahatan ataupun masih mengalami stres, depresi, atau bahkan sampai skizofrenia maka dimungkinkan nilai sholatnya nihil.

Berdasarkan studi pendahuluan yang saya lakukan di Pesantren An-Nur 2 pada tanggal 3 April 2013 selama satu hari. Pernah terjadi kasus bunuh diri. Dari fenomena dan data tersebut maka pentingnya masalah tersebut diteliti, karena peneliti ingin mengetahui dan ingin berkontribusi dalam karya ilmiah dengan dasar hasil penelitian ilmiah serta peneliti ingin menjadikan karya tulis ilmiah ini merupakan acuan dalam salah satu cara memecahkan masalah depresi saat ini.

Berdasarkan dari latar belakang yang penulis uraikan di atas, maka diperlukan penelitian dengan judul Pengaruh sholat tahajud terhadap depresi pada santri di Pesantren An-Nur 2 Bululawang Malang.

\section{METODE PENELITIAN}

Desain yang digunakan dalam penelitian ini menggunakan desain eksperimental yaitu Pre Eksperimen dengan one group pre test post test design (Nursalam, 2003).

Penelitian ini dilakukan di Pesantren An-Nur 2 Bululawang. Waktu penelitian dimulai pada minggu ke dua sampai akhir minggu ke tiga bulan Juli 2013 dengan frekuensi perlakuan sebanyak tujuh kali dalam tujuh hari.

Populasi dalam penelitian ini adalah santri laki-laki kelas tiga di Pesantren An Nur 2 Bululawang dengan jumlah 58 Santri. Sampel penelitiannya adalah semua santri kelas tiga di pesantren An-Nur 2 Bululawang Malang sebanyak 6 (dari screening awal 17 orang yang masuk kriteria inklusi namun pada akhirnya hanya tersisa 6 orang yang melaksanakan intervensi secara menyeluruh). Cara pengambilan sampel pada penelitian ini menggunakan teknik purposive sampling.

Sebagai variabel bebas adalah pengaruh sholat tahajud dan yang menjadi variabel terikat adalah depresi. 
Jurnal CARE, Vol. 2, No. 2, 2014

Data variabel dependen dalam penelitian ini yaitu depresi diukur dengan kuesioner. Alat ukur yang digunakan unutk mengukur tingkat depresi menggunakan skala HRS-D (Hamilton Rating Scale Depression). Pengukuran didasarkan pada 17 ( tujuh belas ) dengan alternatif jawaban. Hasil dari jawaban responden akan dianalisa secara univariat menjadi tidak ada depresi, ringan, sedang, berat, dan sangat berat.

Analisa bivariat yang digunakan dalam penelitian adalah uji wilcoxon yang menggunakan bantuan SPSS for versi 19 dengan taraf signifikan $\alpha=0,05$, dengan interpretasi nilai $\alpha<0,05$ artinya H1 diterima yaitu ada pengaruh antara variabel dependen dan variabel independen. Apabila $\alpha>0,05$ artinya $\mathrm{H} 1$ ditolak yaitu tidak ada pengaruh antara variabel dependen dan variabel independen.

\section{HASIL DAN PEMBAHASAN}

\section{HASIL}

Tabel 1. Karakteristik Umum Responden Santri Pesantren An Nur 2 Bululawang Tahun 2013

\begin{tabular}{rrr}
\hline Karakteristik Umum & $\mathbf{n}$ & $\mathbf{\%}$ \\
\hline Tempat Tinggal & & \\
Kota Malang & 4 & 66 \\
Kabupaten Malang & 1 & 17 \\
Luar Malang & 1 & 17 \\
\hline
\end{tabular}

\section{Data Khusus}

Tabel 2. Data Tingkat Depresi Sebelum dan Sesudah Melakukan Sholat Tahajud Santri Pesantren An Nur 2 Bululawang Tahun 2013

\begin{tabular}{rcc}
\hline Variabel & $\mathbf{n}$ & $\mathbf{\%}$ \\
\hline Tingkat Depresi & & \\
Sebelum Perlakuan & & \\
Tidak Ada Depresi & 0 & 0 \\
Ringan & 0 & 0 \\
Sedang & 4 & 66 \\
Berat & 1 & 17 \\
Tingkat Depresi & & 17 \\
Setelah Perlakuan & & \\
Tidak Ada Depresi & 2 & 33 \\
Ringan & 3 & 50 \\
Sedang & 0 & 0 \\
Berat & 1 & 17 \\
Sangat Berat & 0 & 0 \\
\hline
\end{tabular}

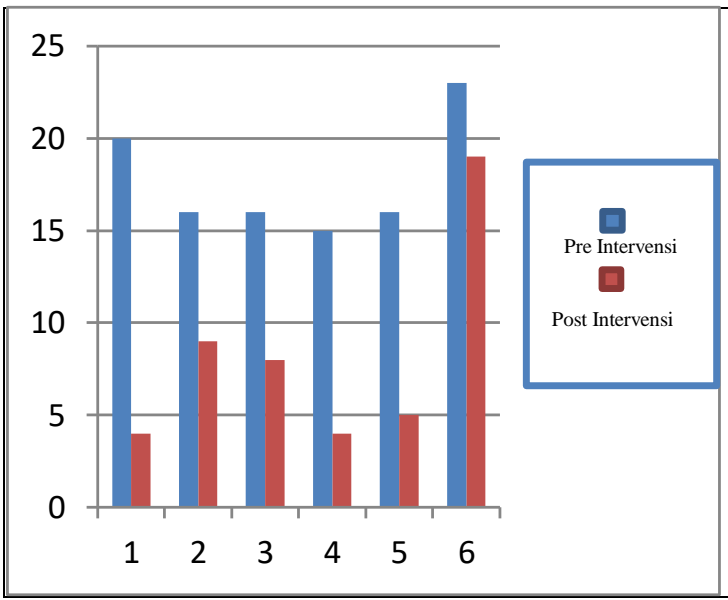

Gambar 1. Tingkatan depresi pre intervensi dan post intervensi depresi pada santri di Pesantren An-Nur 2 Bululawang Tahun 2013.

Tabel 3. Analisa Statistik Pengaruh Sholat Tahajud Terhadap Depresi Pada Santri Di Pesantren An-Nur 2 Bululawang Malang

\begin{tabular}{lr}
\hline & Post_Intervensi \\
& -Pre_Intervensi \\
\hline $\mathrm{Z}$ & $-2.207^{\mathrm{a}}$ \\
Asymp. Sig. (2-tailed) & .027 \\
\hline
\end{tabular}


Jurnal CARE, Vol. 2, No. 2, 2014

\section{PEMBAHASAN}

\section{a. Depresi Sebelum Perlakuan}

Berdasarkan hasil penelitianyang dilakukan diketahui bahwa santri yang mengalami depresi sedang pada pre intervensi sebanyak 4 orang $(66 \%)$, tingkat depresi berat sebanyak 1 orang $(17 \%)$ dan yang mengalami depresi sangat berat ada 1 orang $(17 \%)$.

Umur juga mempengaruhi tingktan depresi pada remaja.Sebanyak 6 (100\%) responden berumur 18 tahun.Peneliti mengatakan masa ini adalah masa puber.Pada masa ini mulai terjadi perubahan secara fisik dan mental dan merupakan masa transisi pada remaja.Bisa dikatakandepresi gampang terjadi pada remaja karena remaja sangat memerhatikan citra diri dan penampilan diri agar bisa tampil sempurna didepan orang. Peneliti yakin, pada masa ini santri akan rentan mengalami stres, tekanan akibat beradaptasi dalam berinteraksi dengan orang lain.Depresi pada remaja harus segera ditangani karena jika berkepanjangan, dapat mengakibatkan bunuh diri yang berujung pada kematian. Makin lama seseorang mengalami depresi, makin lemah daya tahan mentalnya, makin habis energinya, makin habis semangatnya, makin terdistorsi pola pikirnya sehingga dia tidak bisa melihat alternatif solusi untuk menangani depresinya, tidak bisa melihat ke depan, tidak menemukan harapan, tidak bisa berpikir positif juga dapat mempengaruhi kualitas depresi yang terjadi pada seseorang. Secara tidak langsung jika dihubungkan pada perilaku bunuh diri, bunuh diri juga menjadi solusi satu-satunya untuk menyelesaikan atau menghakhiri depresinya.Dalam penelitian di Pesantren An-Nur 2 Bululawang Malang, peneliti mendapatkan bahwa pernah terjadi tindakan bunuh diri yang dilakukan oleh santri beberapa tahun yang lalu.Menurut Kaplan ( 2010) dalam Sari (2011) penurunan serotonin dapat mencetuskan depresi, dan pada pasien bunuh diri, beberapa pasien memiliki serotonin yang rendah.
Selain itu kecemasan psikologis juga sangat dominan yang di alami santri. Lihat saja berdasarkan hasil penelitian sebanyak 66,66 \% depresi juga disebabkan oleh tekanan dan temperamental. Bisa dikatakankehidupandi Pesantren menyebabkan para santri menjadi penuh tekanan, baik karena kehidupan di Pesantren atau karena tekanan dari luar pesantren yang menyebabkan terjadinya depresi pada santri. Peneliti menafsirkan hampir seluruh santri merasakan hal yang sama. Berbagai peristiwa hidup yang menyenangkan dan menyedihkan dapat memicu terjadinya depresi pada santri.Bisa dikatakan stressor psikososial sangat berpengaruh menyebabkan depresi.Stressor psikososial yang bersifat akut, seperti kehilangan orang yang dicintai dapat menyebabkan depresi pada santri.Stressor lingkungan yang paling berhubungan dengan onset suatu episode depresi adalah kehilangan pasangan (Kaplan 2010 dalam Sari 2011).

\section{b. Depresi Post Intervensi}

Berdasarkan hasil penelitian ini, sholat tahajud berpengaruh dalam menurunkan tingkatan depresi yang dialami santri.Lihat saja persentase tingkatan depresi yang di alami santri setelah melaksanakan sholat tahajud. Sebanyak $(17 \%) 1$ orang santri mengalami depresi berat, sebanyak $(50 \%) 3$ orang mengalami depresi sedang dan sebanyak (33\%) 2 orang tidak mengalami depresi.

Ini merupakan suatu hasil yang sangat signifikan.Setelah diberikan perlakuan berupa sholat tahajud selama tujuh kali perlakuan selama satu minggu.Sholat tahajud dapat memberikan efek samping yang dapat mempengaruhi tingkatan depresi yang di miliki oleh santri.Meskipun efek sampingnya berbeda-beda yang dirasakan oleh santri.Tapi hal ini merupakan suatu keberhasilan dalam mempengaruhi tingkatan depresi.Maka dalam hal ini peneliti pun bisa mengatakan sholat dapat menurunkan tingkatan depresi yang miliki oleh manusia. Ini tercermin dalam QS, Al Baqarah, 2 : 45-46 "Jadikan sabar dan Sholat sebagai penolongmu, dan 
Jurnal CARE, Vol. 2, No. 2, 2014

sesungguhnya yang demikian itu sungguh amat berat, kecuali bagi orang-orang yang khusyu, (yaitu) orang-orang yang menyakini, bahwa mereka akan menemui tuhannya, dan bahwa mereka kembali kepada-Nya.

Dari redaksi diatas mejelaskan bahwa meminta pertolongan kepada Allah dalam urusan dunia dan akhirat haruslah menggunakan sholat sebagai sarana penghubung.Ungkapan yang mudah dikatakan tapi sulit untuk di fahami.

Berdasarkan hasil penelitian mengenai frekuensi sholat tahajud sebanyak $(100 \%) \quad 6$ responden, seluruhnya melaksanakan sholat malam sebanyak 7 kali dalam satu minggu. Peneliti beranggapan jika sholat dilakukan terus menerus akan menjadi saran mendekatkan diri kepada sang ilahi dan meningkatakan tingkat keimanan dari seseorang. Pengulangan ini memiliki kekuatan untuk mensugesti menghipnosa mental yang gelisah dan bingung atau memasukkan (menenggelamkan) pikiran kedalam ketenangan yang luar biasa (Sangkan, 2009).Peneliti juga merasakan bahwa intervensi yang diberikan belum cukup untuk menurunkan tingkatan sholat tahajud pada responden.Sehingga masih ada responden yang mengalami depresi berat.

\section{c. Pengaruh Sholat Tahajud Terhadap Depresi}

Penelitian ini memberikan hasil yakni ada pengaruh yang signifikan antara depresi dengan sholat tahajud, yang dibuktikan dengan nilai $\rho$ value sebesar $0,027<\alpha 0,05$. Menyadari bahwa sebagian besar responden dalam keadaan depresi.Peneliti mencoba menggunakan dimensi spiritual berupa sholat tahajud sebagai media dalam menurunkan tingkatan depresi.Tetapi hal mendasarkan harus diketahui oleh responden adalah manfaat sholat tahajud.Karena didalam sholat tahajud tersebuh dapat menyehatkan menyehatkan badan.Hal ini sesuai dengan riwayat Nabi Muhammad s.a.w yang bersabda sebagaimana yang disebutkan dalam hadis riwayat thobroni, "Kerjakanlah sholat malam, karena sesungguhnya ia akan mengusir penyakit dalam tubuh.'”Dan Wahana pendekatan diri kepada Allah s.w.t, penghapus dosa dan pengusir penyakit dalam tubuh. (HR.at-Tirmidzi)

Peneliti beranggapan shalat tahajud dapat memberikan pengaruh secara maksimal harusnya shalat tahajud dijalankan dengan ikhlas dan akan memperbaiki emosional positif dan efektivitas coping. Meski belum banyak teori membahas mengenai keikhlasan dalam melaksanakan perintah agama.Emosional positif sendiri menurut peneliti dapat menghindari reaksi depresi berlebihan. Sholat yang dilaksanakan dengan hudhur (konsentrasi) dan tuma'ninah (tenang) sudah terbukti memberi pengaruh kesehatan bagi manusia, baik fisik, jiwa, sosial, maupun spiritual (Assegaf,2008 dalam Putra, 2012). Jadi, baik Sholat wajib maupun sholat-sholat sunnah, termasuk disini sholat tahajud telah terbukti memberikan manfaat bagi kesehatan.

\section{KESIMPULAN}

Penelitian tentang pengaruh sholat tahajud terhadap depresi pada santri di Pesantren An-Nur 2 Bululawang, menyimpulkan bahwa:

1. Sebelum perlakuan sholat tahajud, sebanyak $66 \%$ responden di Pondok Pesantren An-Nur 2 Bululawang mengalami depresi sedang, $17 \%$ responden mengalami depresi berat dan $17 \%$ responden mengalami depresi sangat berat.

2. Setelah diberikan perlakuan berupa sholat tahajud. Depresi pada santri di Pondok Pesantren An-Nur 2 Bululawang dalam kategori tidak ada depresi sebanyak 33\%, sebanyak 50\% responden termasuk depresi ringan dan sebanyak $17 \%$ responden termasuk depresi berat

3. Adapengaruh yang signifikan antara "Pengaruh sholat tahajud terhadap depresi pada santri di Pesantren AnNur 2 Bululawang", dimana p-value sebesar $0.027<0.05$ maka H0 di tolak. 
Jurnal CARE, Vol. 2, No. 2, 2014

\section{DAFTAR PUSTAKA}

Arikunto, S. 2010. Prosedur Penelitian, Suatu Pendekatan Praktek. Rineka Cipta: Jakarta

Fathiariani,L.2013.Puasa sebagai Terapi Jiwa.http://aceh.tribunnews.com/20 13/07/24/puasa-sebagai-terapi-jiwa Diakses pada 25 Juli.2013.

Ismirayanti. 2010. Depresi. http:/ / ismirayanti.blogspot.com/20 10/10/depresi.html.

Marianne. 2010. Depresi dan Penangannnya.http:// repository.usu.ac .id/handle/123456789/28312.

Diakses pada 14 Juni 2013.

Nursalam. 2011. Konsep dan Penerapan Metodologi Penelitian Ilmu Keperawatan. Jakarta: Salemba Medika

Putra, H, K. 2012. Peranan Shalat Tabajud Dalam Meghadapi Stres Pada Mahasiswa Universitas Sumatera Utara.( http://repository.usu.ac.id/handle/1 23456789/31210). Di akses pada 14 Juni 2013.

Rusydi, A. 2011. Sholat sebagai Psikoterapi Frustasi dan Pencegah Depresi.http:// rumahpencerahan.blo gspot.com/2011/12/sholat-sebagaipsikoterapi-frustasi-dan.html. Di aksess pada 1 Agustus 2013.

Sangkan, A. 2011. Pelatihan Sholat Khusyuk. Cetakan ke 24. Jakarta: Yayasan Shalat Khusyuk \& Manajemen Masjid Baitul Ihsan Bank Indonesia.

Sari, N, N. 2011. Pengaruh Dukungan Sosial Terhadap Depresi Pada Lansia.( http:/ / repository.usu.ac.id/ handle/12345 6789/21410). Di akses 14 Juni 2013.

Supiandi,Y.2012.Depresi.http:/ / supiandiyan di73.blogspot.com/2012_11_01_arc hive.html. Di akses tanggal 18 Juni 2013. 